\title{
Nanoparticles with Near-Infrared Emission Enhanced by Pillararene-Based Molecular Recognition in Water
}

\author{
Bingbing Shi, Kecheng Jie, Yujuan Zhou, Jiong Zhou, Danyu Xia, and Feihe Huang*
}

State Key Laboratory of Chemical Engineering, Center for Chemistry of High-Performance \& Novel Materials, Department of Chemistry, Zhejiang University, Hangzhou, 310027, P. R. China Fax and Tel: +86-571-8795-3189; Email address: fhuang@zju.edu.cn

\section{Supporting Information (17 pages)}

1. Materials and methods $\quad$ S2

2. Synthesis of compounds 1 and $2 \quad$ S3

3. Host-guest studies between WP5 and $2 \quad$ S9

4. Fluorescence spectra of $\mathbf{1}$ at different concentrations S11

5. Fluorescence spectra of the nanoribbons and nanoparticles $\quad$ S11

$\begin{array}{ll}\text { 6. Investigation of the aggregation behaviours } & \mathrm{S} 12\end{array}$

7. Determination of critical aggregation concentration of 1 and $\mathbf{W P 5} \supset \mathbf{1}$ in water $\quad \mathrm{S} 13$

8. Protonation studies of $\mathbf{1}, \boldsymbol{W P 5} \supset \mathbf{1}$, and $\boldsymbol{W P 5} \supset \mathbf{2}$

9. DLS studies of the host-guest complex WP5 $\supset 1$ assemblies

10. Relative cell viabilities $\quad$ S15

11. Confocal images of live HeLa and bEnd.3 cells $\quad$ S15

12. Cell culture and in vitro cytotoxicity assay S16

$\begin{array}{ll}\text { 13. References } & \text { S17 }\end{array}$ 


\section{Materials and methods}

All reagents were commercially available and used as supplied without further purification. Solvents were either employed as purchased or dried according to procedures described in the literature. Water-soluble pillar[5]arene WP5 was prepared according to a published procedure. ${ }^{\mathrm{S} 1}{ }^{1} \mathrm{H}$ NMR and ${ }^{13} \mathrm{C}$ HMR spectra were recorded with a Bruker Avance DMX 400 spectrophotometer using the deuterated solvent as the lock and the residual solvent or TMS as the internal reference. Mass spectra were obtained on a Bruker Esquire 3000 plus mass spectrometer (Bruker-Franzen Analytik GmbH Bremen, Germany) equipped with an ESI interface and an ion trap analyzer. High-resolution mass spectrometric experiments were performed with a Bruker 7-Tesla FT-ICR mass spectrometer equipped with an electrospray source (Billerica, MA, USA). Transmission electron microscopic investigations were carried out on a HITACHI HT-7700 instrument. Scanning electron microscopy investigations were carried out on a JEOL 6390LV instrument. Dynamic light scattering was carried out on a Malvern Nanosizer S instrument at room temperature. UV-vis spectra were taken on a PerkinElmer Lambda $35 \mathrm{UV}$-vis spectrophotometer. The fluorescence experiments were conducted on a RF-5301 spectrofluorophotometer (Shimadzu Corporation, Japan). The ITC experiment was performed on a VP-ITC micro-calorimeter (Microcal, USA). Photographs were taken wiht a Cannon 550D. 
Scheme S1. Synthetic routes to 1 and 2.

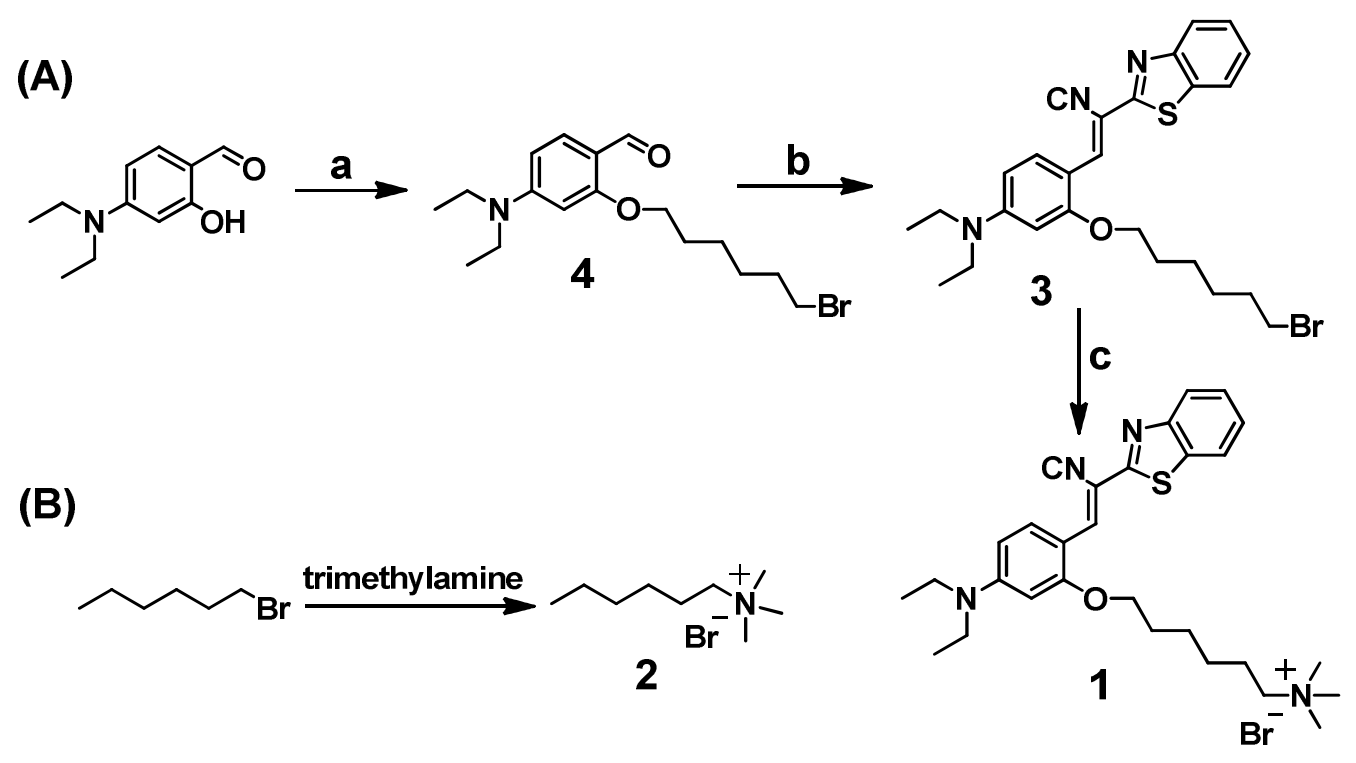

(a) $\mathrm{Br}\left(\mathrm{CH}_{2}\right)_{6} \mathrm{Br}$, THF, NaH, reflux, $3 \mathrm{~d}, 60 \%$; (b) 2-benzothiazolylacetonitrile, ethanol, piperidine, r.t., 12 h, 55\%; (c) trimethylamine, ethanol, r.t., 10 h, 99\%.

Compound $\mathbf{1}$ was prepared according to a literature procedure, ${ }^{\mathrm{S} 2}$ but some changes were made.

2-(4-Bromohexyloxy)-4-(diethylamino)benzaldehyde (4). To a stirred solution of 4-(diethylamino)salicylaldehyde (1.90 g, $10.0 \mathrm{mmol})$ and sodium hydride $(0.300 \mathrm{~g}, 12.0 \mathrm{mmol})$ dissolved in dry THF $(150 \mathrm{~mL})$ was added 1,4-dibromohexane $(3.23 \mathrm{~g}, 15.0 \mathrm{mmol})$ dropwise via a syringe at room temperature. The resulting solution was heated at reflux and stirred for 3 days. After the reaction was complete, the reaction solution was evaporated under reduced pressure and extracted with $\mathrm{CH}_{2} \mathrm{Cl}_{2}$. The combined organic layer was dried over anhydrous $\mathrm{Na}_{2} \mathrm{SO}_{4}$, filtered, and evaporated under reduced pressure. The residue was purified by column chromatography on silica gel using progressively more polar 10:1 to $1: 1$ petroleum ether/ethyl acetate as the mobile phase to give compound $\mathbf{4}$ as a colorless oil (2.13 g, 60\%). ${ }^{1} \mathrm{H}$ NMR (400 MHz, $\left.\mathrm{CDCl}_{3}\right) \delta(\mathrm{ppm}): 10.18(\mathrm{~s}, 1 \mathrm{H}), 7.71(\mathrm{~d}, J=8 \mathrm{~Hz}, 1 \mathrm{H}), 6.28(\mathrm{~s}, 1 \mathrm{H})$, $6.01(\mathrm{~s}, 1 \mathrm{H}), 4.05(\mathrm{t}, J=12 \mathrm{~Hz}, 2 \mathrm{H}), 3.43(\mathrm{t}, J=16 \mathrm{~Hz}, 2 \mathrm{H}), 1.84-1.92(\mathrm{~m}, 4 \mathrm{H}), 1.54(\mathrm{t}, J=8 \mathrm{~Hz}, 4 \mathrm{H})$, $1.22(\mathrm{t}, J=12 \mathrm{~Hz}, 6 \mathrm{H}) .{ }^{13} \mathrm{C}$ NMR $\left(100 \mathrm{MHz}, \mathrm{CDCl}_{3}\right) \delta(\mathrm{ppm}): 187.07,163.78,153.85,130.21,114.27$, $104.30,93.13,67.76,44.78,33.83,32.62,29.00,27.88,25.36,12.62$.

(E)-2-(1,3-Benzothiazol-2-yl)-1-[2-(4-bromohexyloxy)-4-(diethylamino)phenyl]acrylonitrile (3). To a stirred solution of compound $4(0.710 \mathrm{~g}, 2.00 \mathrm{mmol})$ and 2-benzothiazoleacetonitrile $(0.360 \mathrm{~g}, 2.10 \mathrm{mmol})$ in ethanol $(30 \mathrm{~mL})$ at room temperature was added piperidine $(2.10 \mathrm{~mL}, 21.0 \mathrm{mmol})$. The resulting 
mixture was allowed to stir overnight at room temperature. The precipitate formed was collected by filtration. The crude solid was recrystallized from ethanol to afford 3 as an orange solid $(0.560 \mathrm{~g}, 55 \%)$. Mp: $116.2-116.9^{\circ} \mathrm{C} .{ }^{1} \mathrm{H}$ NMR $\left(400 \mathrm{MHz}, \mathrm{CDCl}_{3}\right) \delta(\mathrm{ppm}): 8.50(\mathrm{~s}, 1 \mathrm{H}), 8.43(\mathrm{~d}, J=8 \mathrm{~Hz}, 1 \mathrm{H}), 8.01(\mathrm{~d}, J$ $=8 \mathrm{~Hz}, 1 \mathrm{H}), 7.84(\mathrm{~d}, J=8 \mathrm{~Hz}, 1 \mathrm{H}), 7.46(\mathrm{t}, J=8 \mathrm{~Hz}, 1 \mathrm{H}), 7.43(\mathrm{t}, J=8 \mathrm{~Hz}, 1 \mathrm{H}), 6.34-6.36(\mathrm{~m}, 1 \mathrm{H}), 6.05$ $(\mathrm{s}, 1 \mathrm{H}), 4.04(\mathrm{t}, J=12 \mathrm{~Hz}, 2 \mathrm{H}), 3.42-3.45(\mathrm{~m}, 6 \mathrm{H}), 1.77-1.92(\mathrm{~m}, 4 \mathrm{H}), 1.60(\mathrm{t}, J=8 \mathrm{~Hz}, 4 \mathrm{H}) .{ }^{13} \mathrm{C} \mathrm{NMR}$ $\left(100 \mathrm{MHz}, \mathrm{CDCl}_{3}\right) \delta(\mathrm{ppm}): 166.04,160.59,154.01,152.67,141.25,134.29,130.44,126.34,124.89$, $122.91,121.30,118.58,109.89,105.08,96.19$, 93.66, 68.15, 44.87, 33.89, 32.71, 29.03, 27.93, 25.47, 12.74 .

\section{(E)-4-[2-(1,3-Benzothiazol-2-yl)-2-cyanovinyl]-5-(diethylamino)phenoxy)- $N, N, N$-trimethylhexan-1-a}

minium bromide (1). To a stirred solution of compound $3(0.400 \mathrm{~g}, 0.800 \mathrm{mmol})$ in ethyl alcohol $(40 \mathrm{~mL})$ at room temperature was added trimethylamine $(33.0 \%$ in ethyl alcohol, $3.00 \mathrm{~mL})$. The resulting solution was refluxed for $24 \mathrm{~h}$ in a sealed flask. After removal of the solvent, diethylether was added to give precipitate 1 as an orange solid (0.450 g, 99.0\%). Mp: 222.4-222.9 ${ }^{\circ} \mathrm{C} .{ }^{1} \mathrm{H}$ NMR (400 MHz, CD 3 OD) $\delta$ (ppm): $8.32(\mathrm{~s}, 1 \mathrm{H}), 8.24(\mathrm{~d}, J=8.0 \mathrm{~Hz}, 1 \mathrm{H}), 7.83-7.88(\mathrm{~m}, 2 \mathrm{H}), 7.45(\mathrm{t}, J=16.0 \mathrm{~Hz}, 1 \mathrm{H}), 7.32(\mathrm{t}, J=$ $12.0 \mathrm{~Hz}, 1 \mathrm{H}), 6.32(\mathrm{~d}, J=8.0 \mathrm{~Hz}, 1 \mathrm{H}), 6.02(\mathrm{~s}, 1 \mathrm{H}), 4.02(\mathrm{t}, J=12.0 \mathrm{~Hz}, 2 \mathrm{H}), 3.37-4.41(\mathrm{~m}, 6 \mathrm{H}), 3.13(\mathrm{~s}$, $9 \mathrm{H}), 1.87-1.92(\mathrm{~m}, 4 \mathrm{H}), 1.62-1.60(\mathrm{~m}, 2 \mathrm{H}), 1.48-1.56(\mathrm{~m}, 2 \mathrm{H}), 1.19(\mathrm{t}, J=16.0 \mathrm{~Hz}, 6 \mathrm{H}) .{ }^{13} \mathrm{C} \mathrm{NMR}(100$ $\left.\mathrm{MHz}, \mathrm{CD}_{3} \mathrm{OD}\right) \delta(\mathrm{ppm}): 168.03,162.48,154.89,154.67,142.58,135.15,131.08,127.73,126.27,123.24$, $122.69,119.48,110.61,106.26,95.14,94.81,69.25,67.83,53.60,45.86,30.02,27.18,26.94,24.09$, 13.15. LRESIMS: $m / z 491.9\left[\mathbf{1}-\mathrm{Br}^{-}\right]^{+}(100 \%)$. HRESIMS: $m / z$ calcd for $\left[\mathbf{1}-\mathrm{Br}^{-}\right]^{+} \mathrm{C}_{29} \mathrm{H}_{39} \mathrm{~N}_{4} \mathrm{OS}^{+}$, 491.2839, found 491.2836, error $0.6 \mathrm{ppm}$.

$\boldsymbol{N}, \boldsymbol{N}, \mathbf{N}$-trimethylhexan-1-aminium bromide (2). To a stirred solution of 1-bromohexane (1.65 g, 10.0 $\mathrm{mmol})$ in ethyl alcohol $(40 \mathrm{~mL})$ at room temperature was added trimethylamine $(33.0 \%$ in ethyl alcohol, 4 $\mathrm{mL}$ ). The resulting solution was refluxed for $24 \mathrm{~h}$. The mixture was concentrated under reduced pressure to give compound 2 as a colorless oil (2.19 g, 98\%). ${ }^{1} \mathrm{H}$ NMR (400 MHz, $\left.\mathrm{D}_{2} \mathrm{O}\right) \delta(\mathrm{ppm}): 3.20-3.23$ (m, 2H), 3.00-3.02 (m, 9H), $1.68(\mathrm{~s}, 2 \mathrm{H}), 1.24(\mathrm{~s}, 6 \mathrm{H}), 0.78(\mathrm{t}, J=8.0 \mathrm{~Hz}, 3 \mathrm{H}) .{ }^{13} \mathrm{C} \mathrm{NMR}\left(100 \mathrm{MHz}, \mathrm{D}_{2} \mathrm{O}\right) \delta$ (ppm): 66.77, 52.80, 30.39, 25.07, 22.17, 21.67, 13.02. 


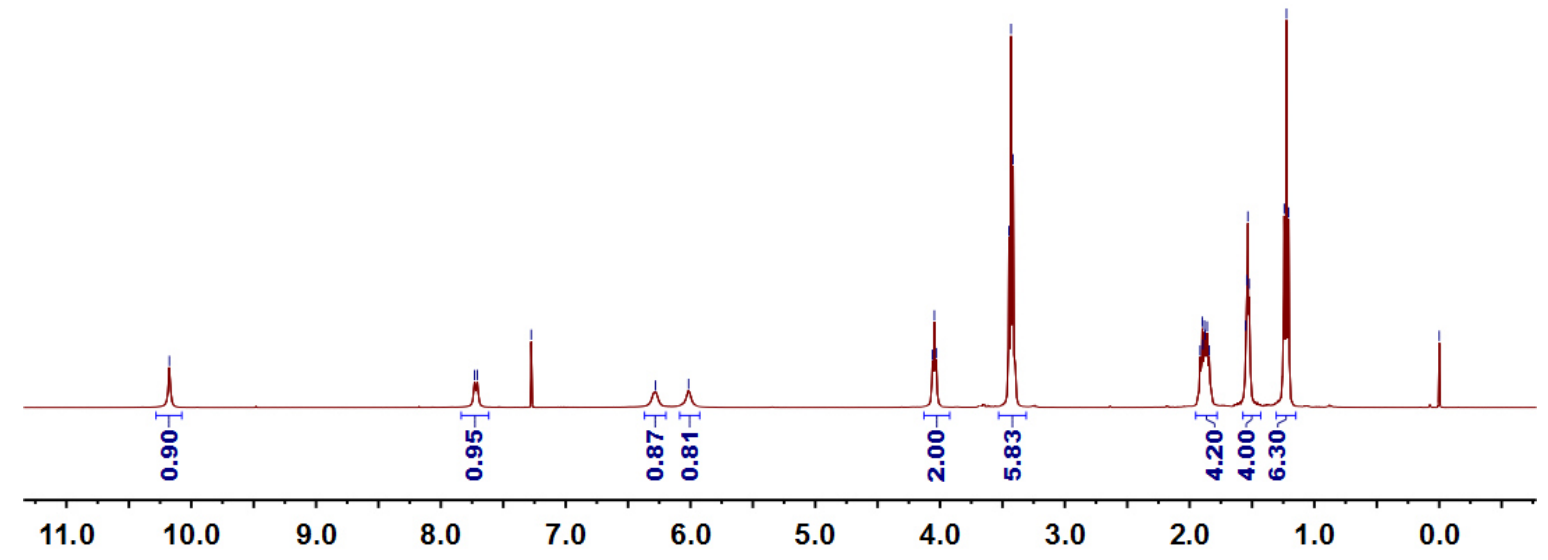

Figure S1. ${ }^{1} \mathrm{H}$ NMR spectrum $\left(400 \mathrm{MHz}, \mathrm{CDCl}_{3}, 293 \mathrm{~K}\right)$ of 4.

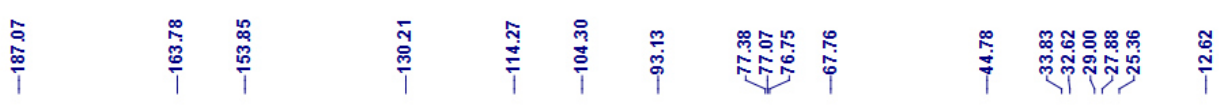

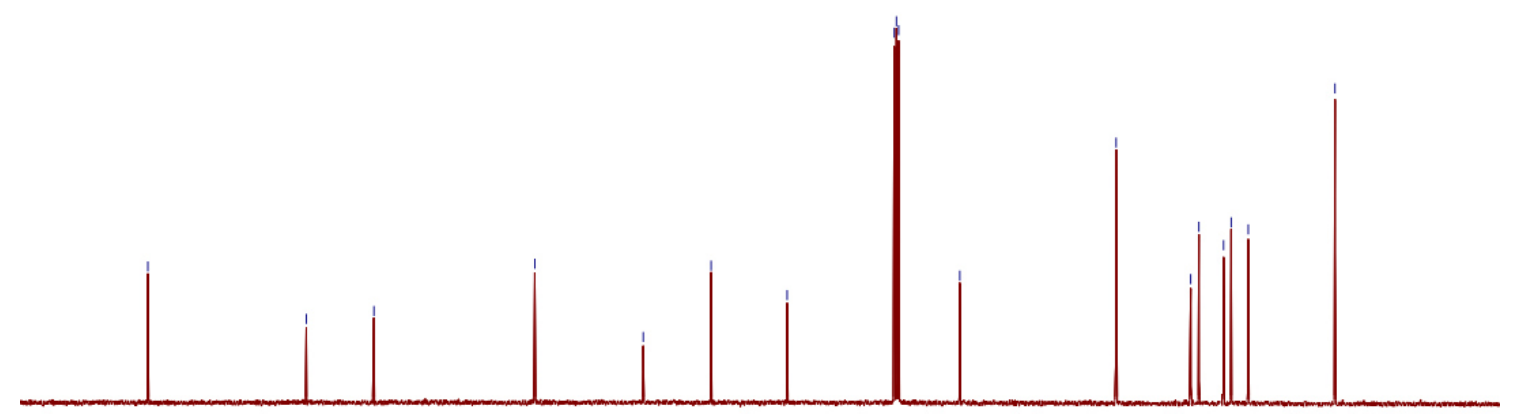

190
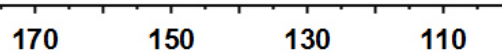

90

8070

Figure S2. ${ }^{13} \mathrm{C}$ NMR spectrum $\left(100 \mathrm{MHz}, \mathrm{CDCl}_{3}, 293 \mathrm{~K}\right)$ of 4 . 


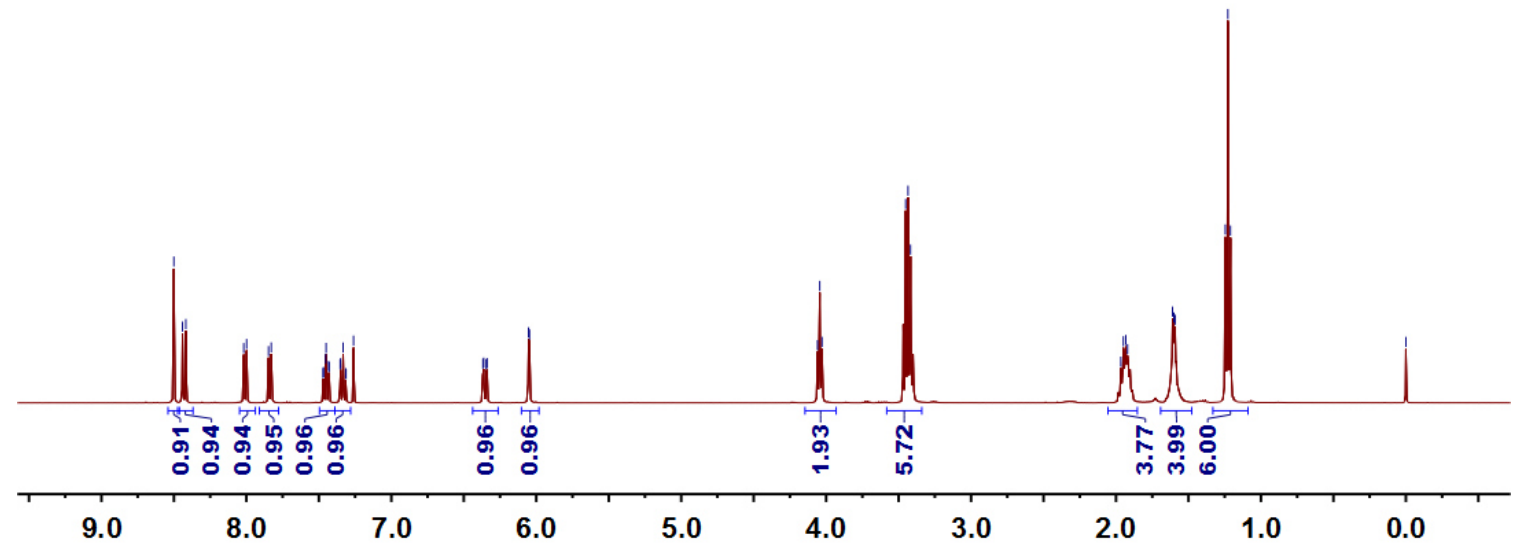

Figure S3. ${ }^{1} \mathrm{H}$ NMR spectrum $\left(400 \mathrm{MHz}, \mathrm{CDCl}_{3}, 293 \mathrm{~K}\right)$ of 3.

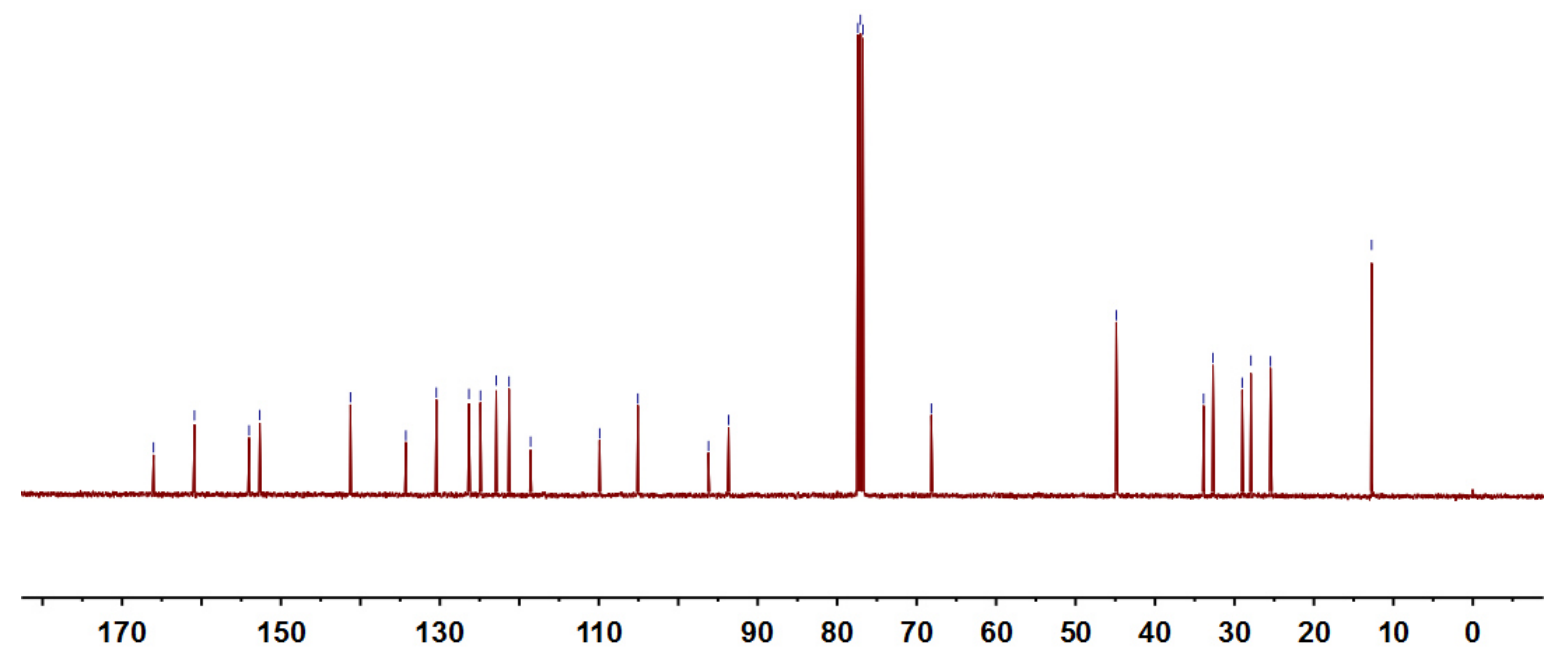

Figure S4. ${ }^{13} \mathrm{C}$ NMR spectrum $\left(100 \mathrm{MHz}, \mathrm{CDCl}_{3}, 293 \mathrm{~K}\right)$ of 3. 


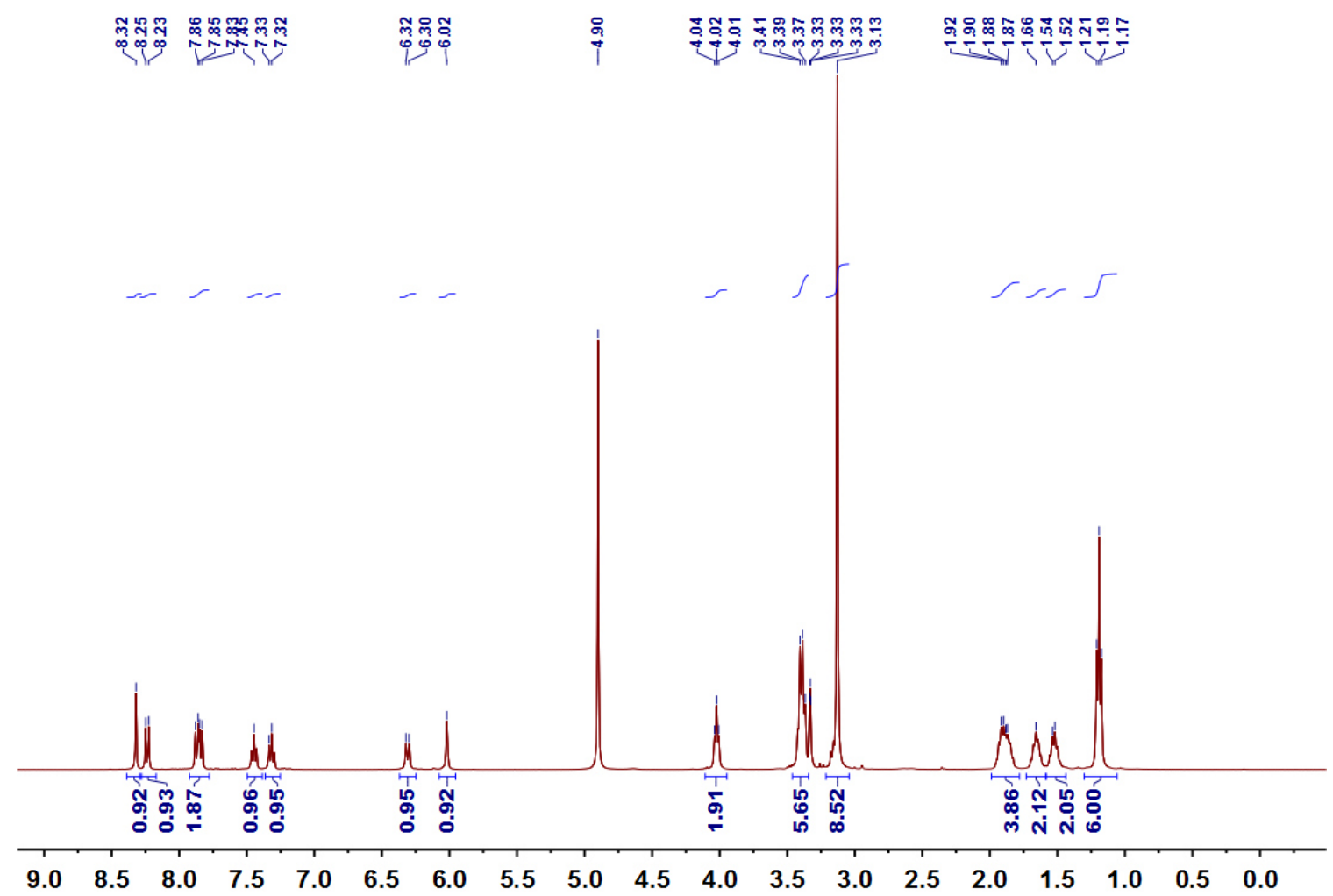

Figure S5. ${ }^{1} \mathrm{H}$ NMR spectrum (400 MHz, $\left.\mathrm{CD}_{3} \mathrm{OD}, 293 \mathrm{~K}\right)$ of $\mathbf{1}$.

龸
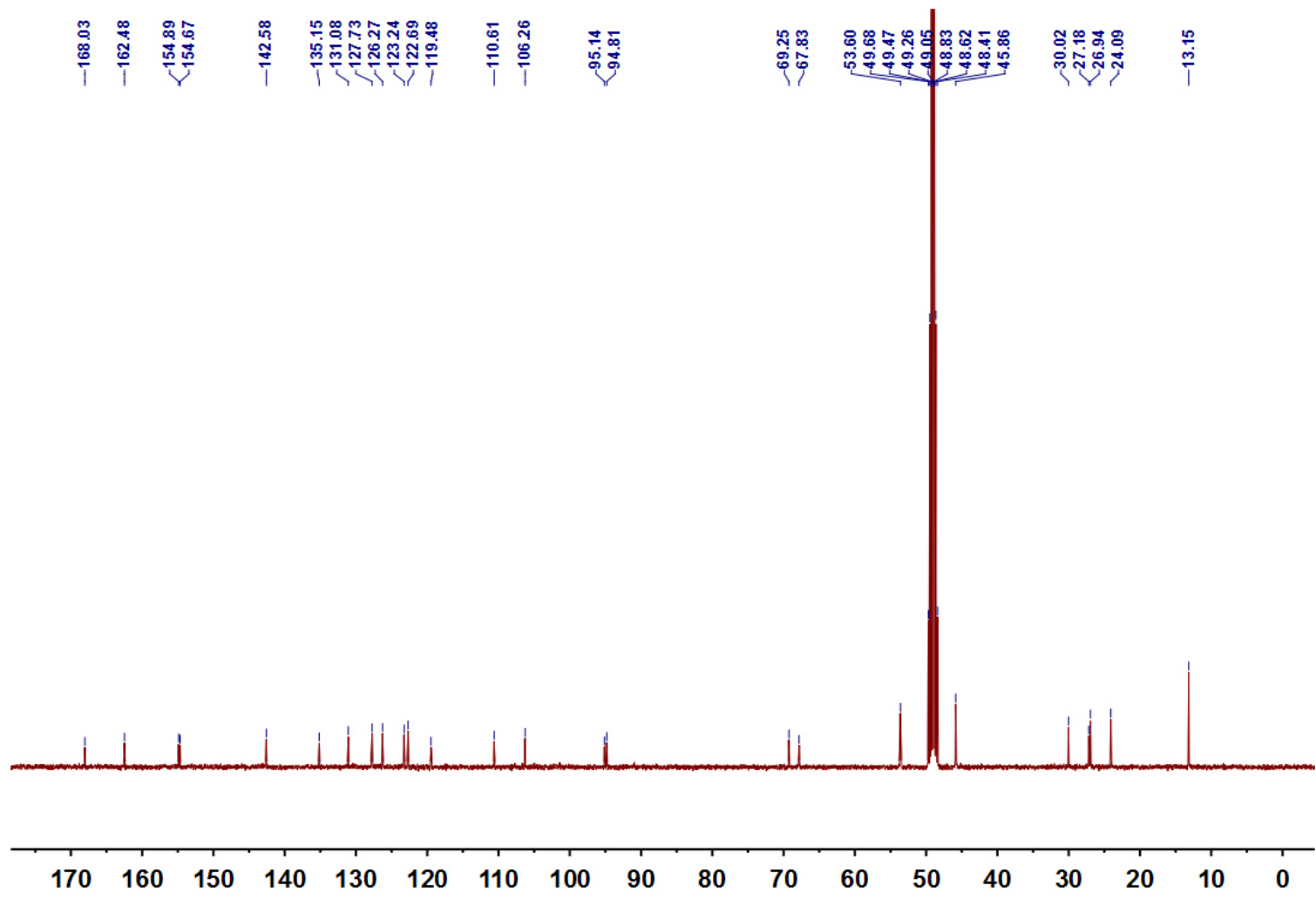

Figure S6. ${ }^{13} \mathrm{C}$ NMR spectrum $\left(400 \mathrm{MHz}, \mathrm{CD}_{3} \mathrm{OD}, 293 \mathrm{~K}\right)$ of $\mathbf{1}$. 


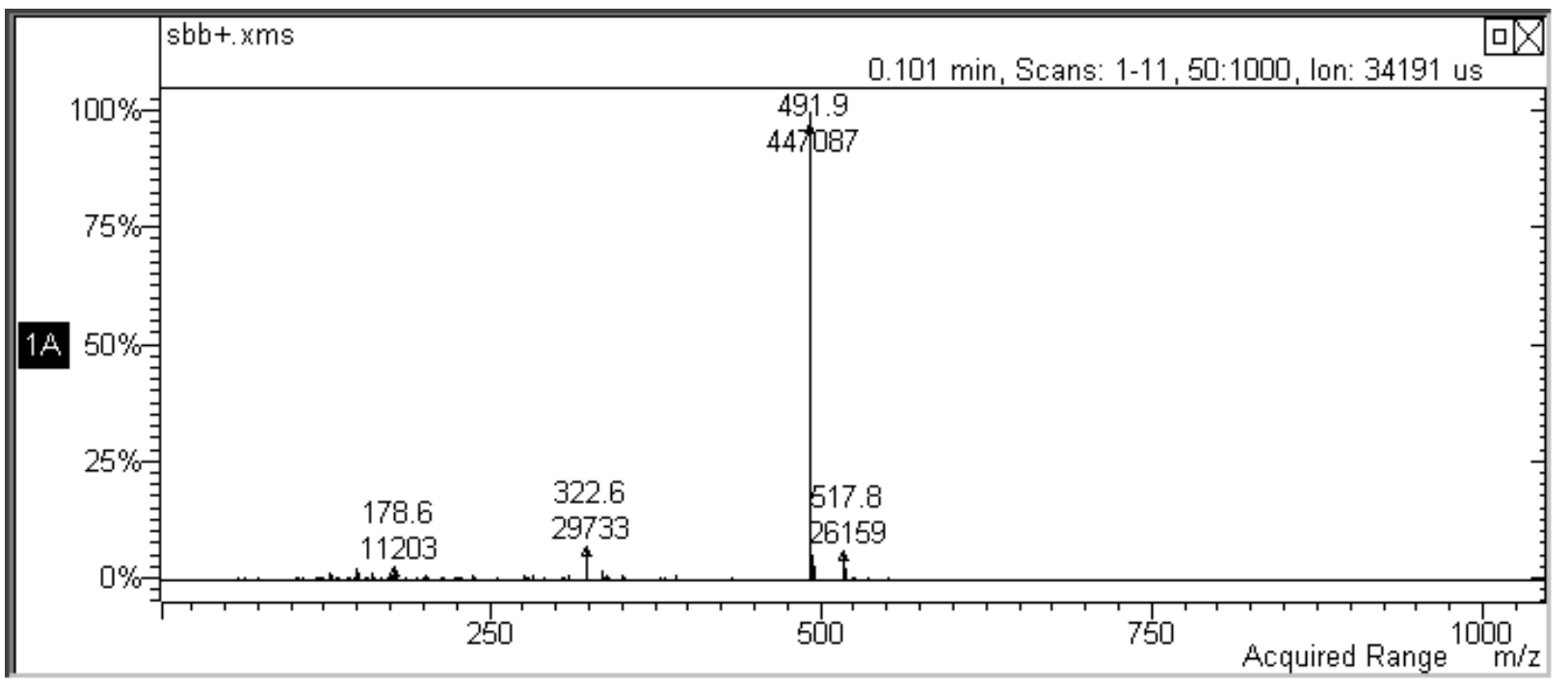

Figure S7. Electrospray ionization mass spectrum of 1. Assignment of the main peak: $m / z 491.9\left[1-\mathrm{Br}^{-}\right]^{+}$.

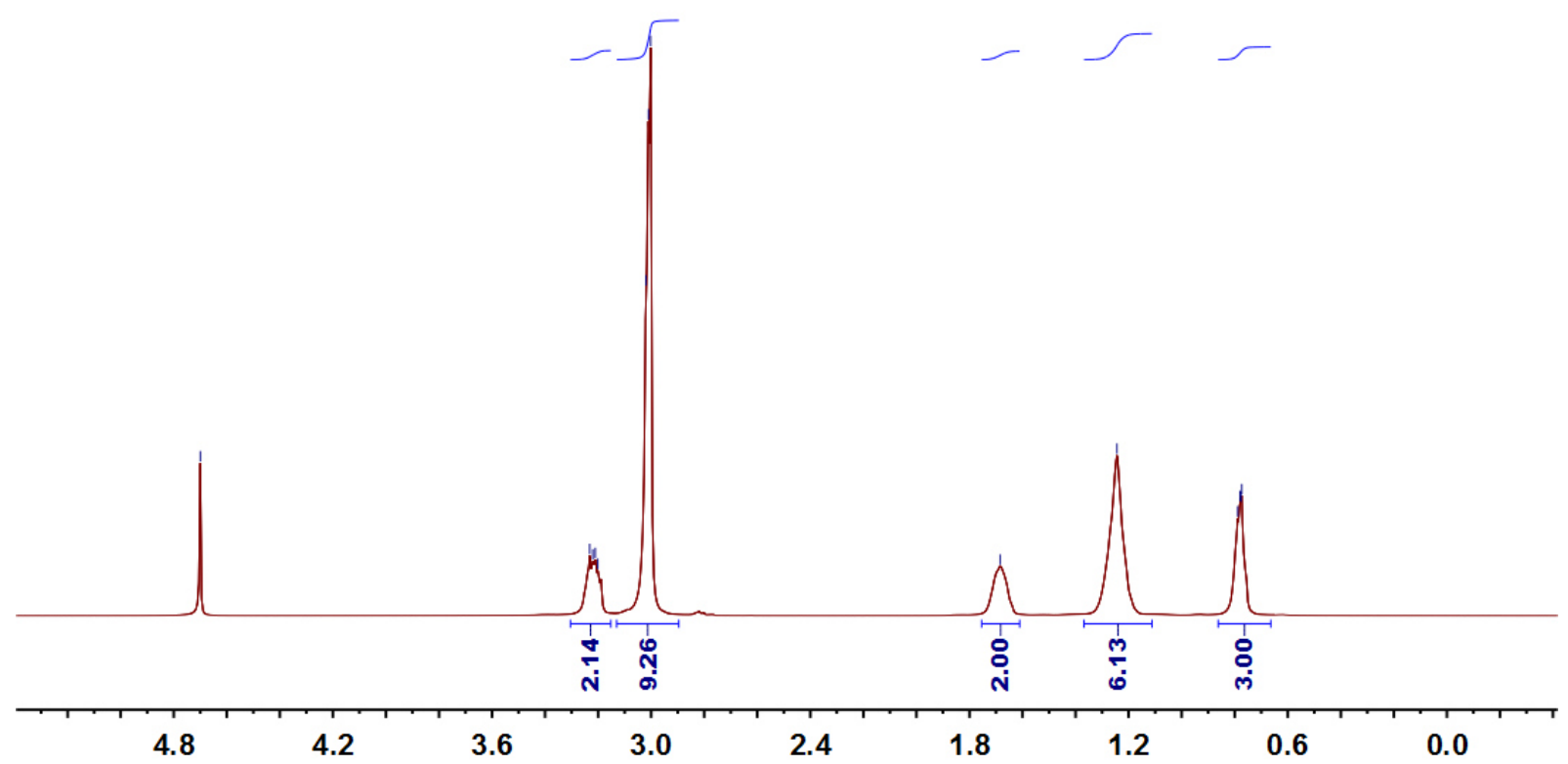

Figure S8. ${ }^{1} \mathrm{H}$ NMR spectrum $\left(400 \mathrm{MHz}, \mathrm{D}_{2} \mathrm{O}, 293 \mathrm{~K}\right)$ of 2. 


密

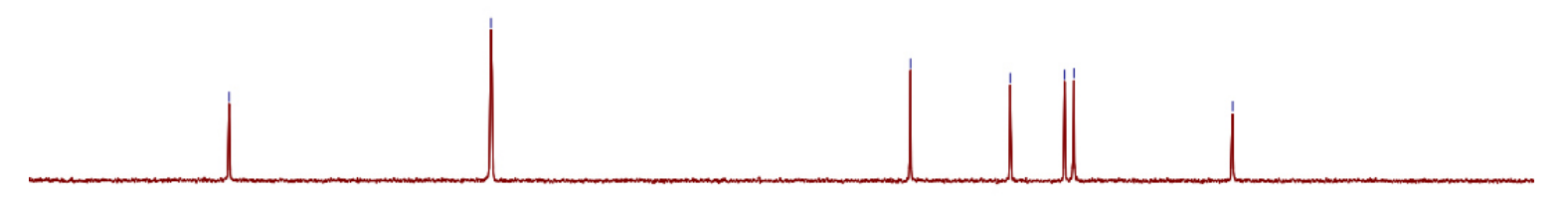

\begin{tabular}{llllllllllllllll}
\hline 75 & 70 & 65 & 60 & 55 & 50 & 45 & 40 & 35 & 30 & 25 & 20 & 15 & 10 & 5 & 0
\end{tabular}

Figure S9. ${ }^{13} \mathrm{C}$ NMR spectrum $\left(400 \mathrm{MHz}, \mathrm{D}_{2} \mathrm{O}, 293 \mathrm{~K}\right)$ of 2.

3. Host-guest studies between 2 and WP5

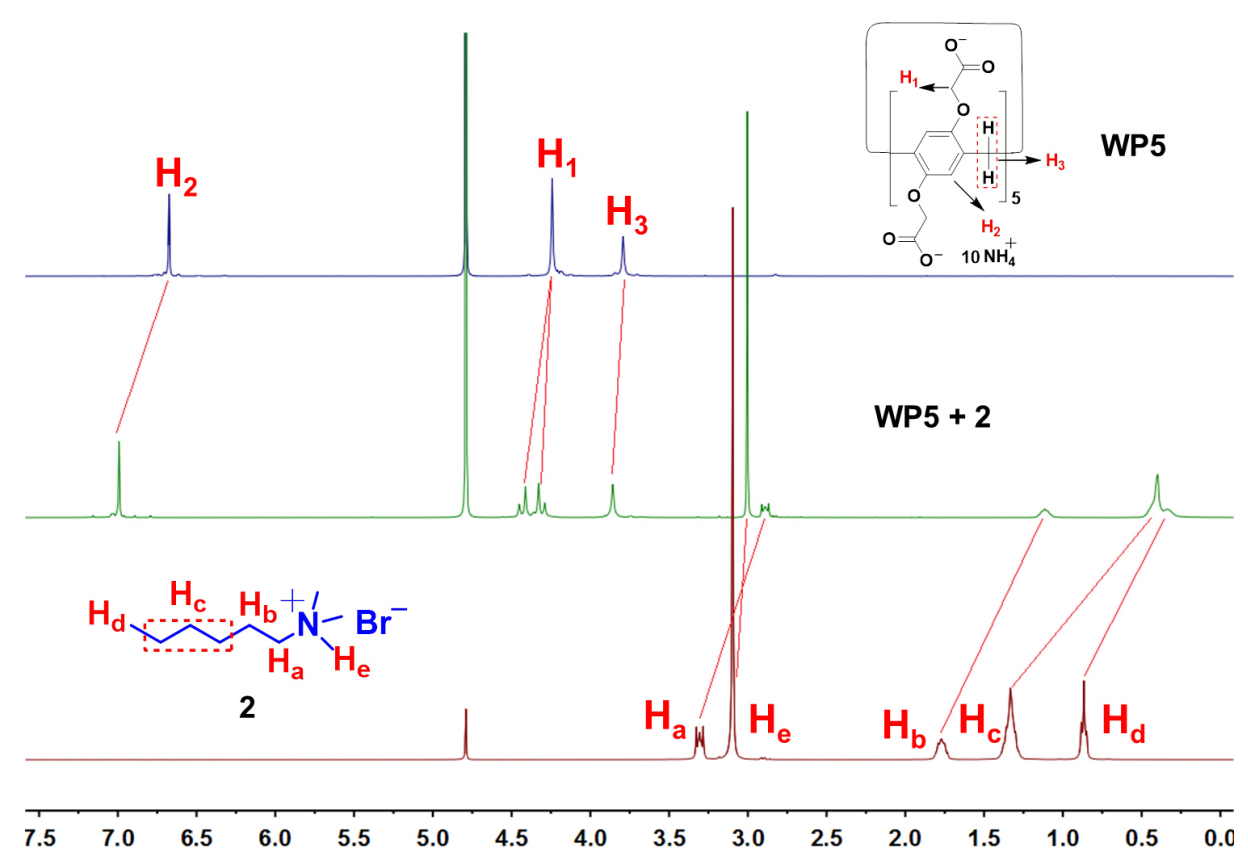

Figure S10. Partial ${ }^{1} \mathrm{H}$ NMR (400 Hz, $\left.\mathrm{D}_{2} \mathrm{O}, 293 \mathrm{~K}\right)$ spectra: (a) WP5 (10.0 mM); (b) WP5 (10.0 mM) and 2 (10.0 $\mathrm{mM})$; (c) model compound 2 (10.0 mM). 


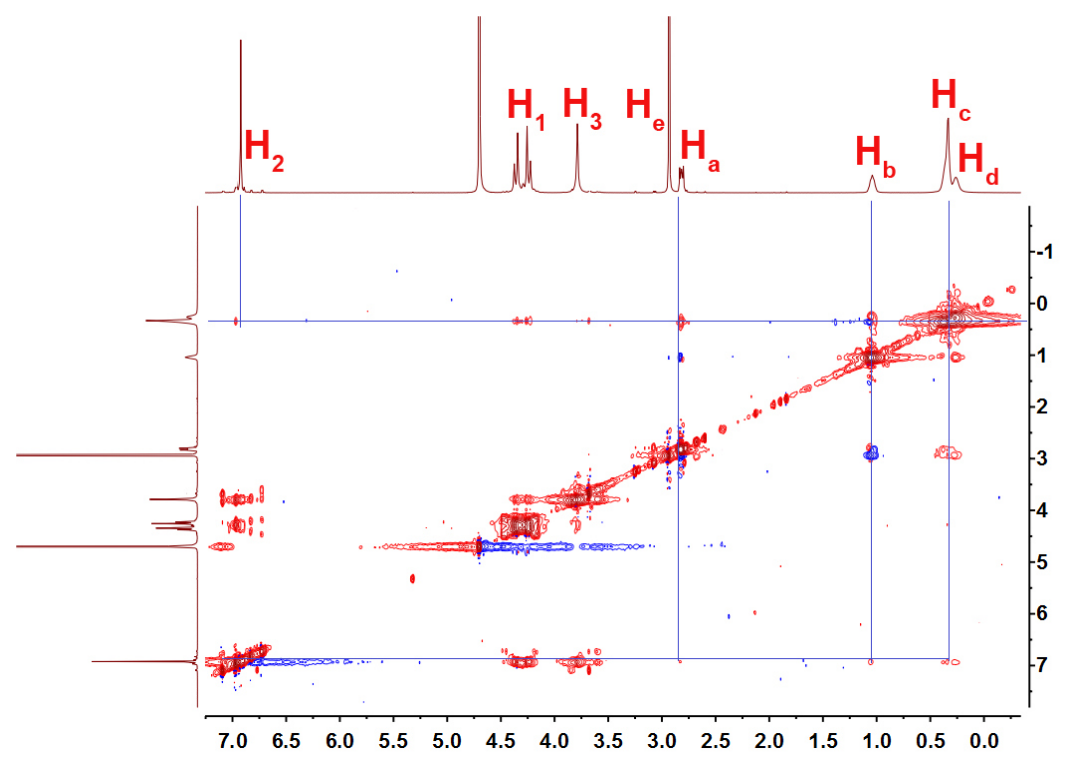

Figure S11. 2D NOESY NMR (500 MHz, $\left.\mathrm{D}_{2} \mathrm{O}, 293 \mathrm{~K}\right)$ spectrum of a solution of WP5 $(10.0 \mathrm{mM})$ and $2(10.0$ $\mathrm{mM})$.

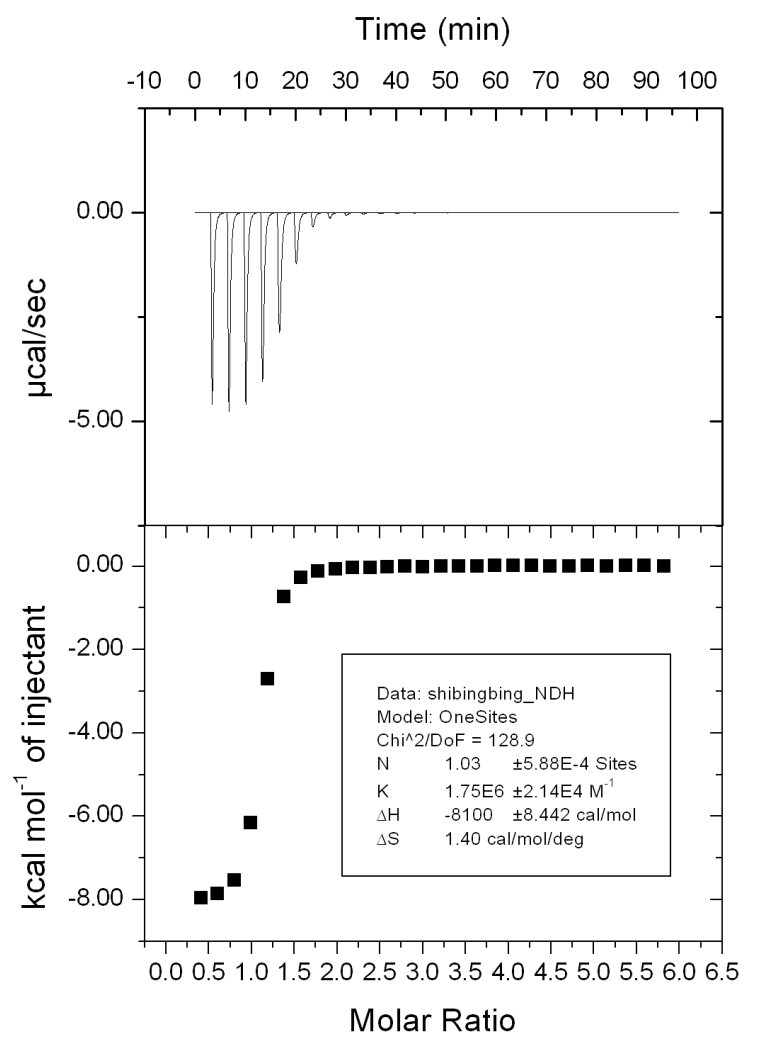

Figure S12. Microcalorimetric titration of 2 with WP5 in pure water at 298.15 K. (Top) Raw ITC data for 27 sequential injections (10.0 $\mu \mathrm{L}$ per injection) of a 2 solution $(2.00 \mathrm{mM})$ into a WP5 solution $(0.100 \mathrm{mM})$. (Bottom) Net reaction heat obtained from the integration of the calorimetric traces. 
(a)

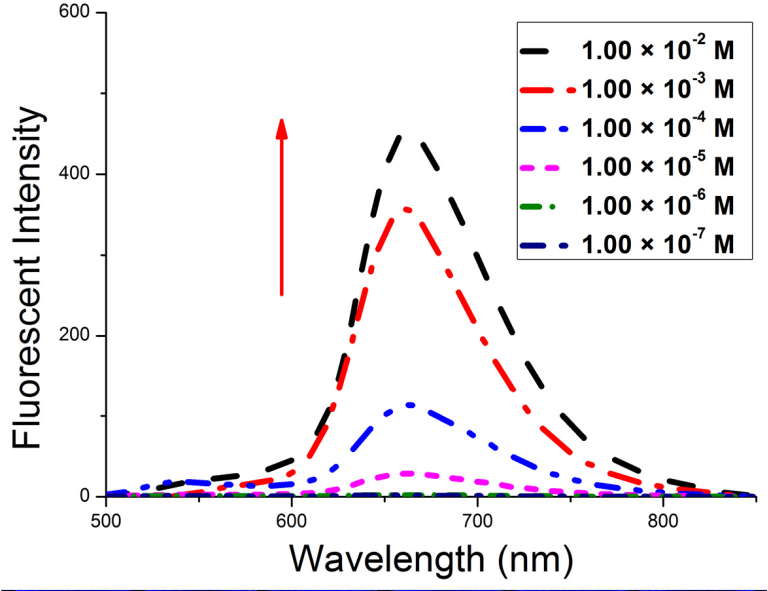

(b) $10^{-2} \mathrm{M} 10^{-3} \mathrm{M} 10^{-4} \mathrm{M} 10^{-5} \mathrm{M} 10^{-6} \mathrm{M} 10^{-7} \mathrm{M}$

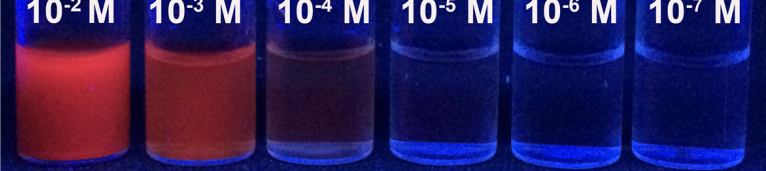

Figure S13. Fluorescence spectra of 1 at different concentrations in aqueous PBS buffer solution $\left(1.00 \times 10^{-2} \mathrm{M}\right.$ PBS, $\mathrm{pH}=7.4)$ at room temperature $\left(\lambda_{\mathrm{ex}}=470 \mathrm{~nm}\right)$. Inset: photograph of 1 at different concentrations under a UV-lamp (365 nm).

\section{Fluorescence spectra of the nanoribbons and nanoparticles}

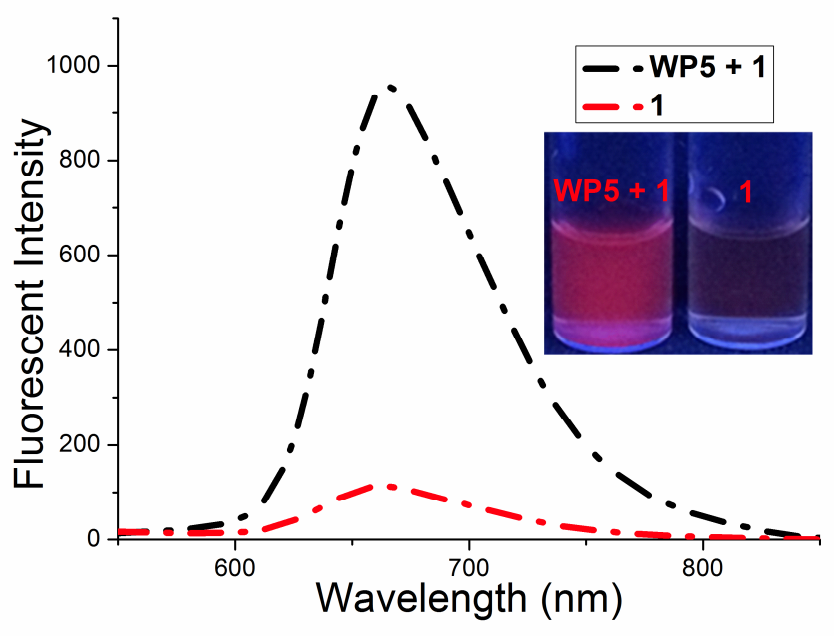

Figure S14. Fluorescence spectra of the nanoribbons self-assembled from $1\left(1.00 \times 10^{-4} \mathrm{M}\right)$ and nanoparticles self-assembled from WP5 $\supset \mathbf{1}$ complex $\left(1.00 \times 10^{-4} \mathrm{M}\right)$ in aqueous PBS buffer solution $\left(1.00 \times 10^{-2} \mathrm{M}\right.$ PBS, $\mathrm{pH}=$ $\left.7.4, \lambda_{\mathrm{ex}}=470 \mathrm{~nm}\right)$. Inset: photograph of the nanoribbons and nanoparticles under a UV-lamp $(365 \mathrm{~nm})$. 


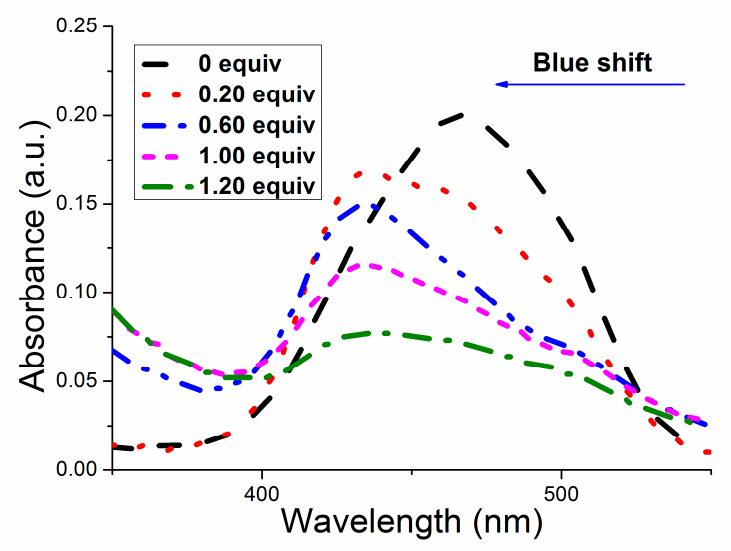

Figure S15. Absorption spectra of $1\left(2.00 \times 10^{-5} \mathrm{M}\right)$ in the presence of different concentrations of WP5 in aqueous PBS buffer solution $\left(1.00 \times 10^{-2} \mathrm{M}\right.$ PBS, $\left.\mathrm{pH}=7.4\right)$.

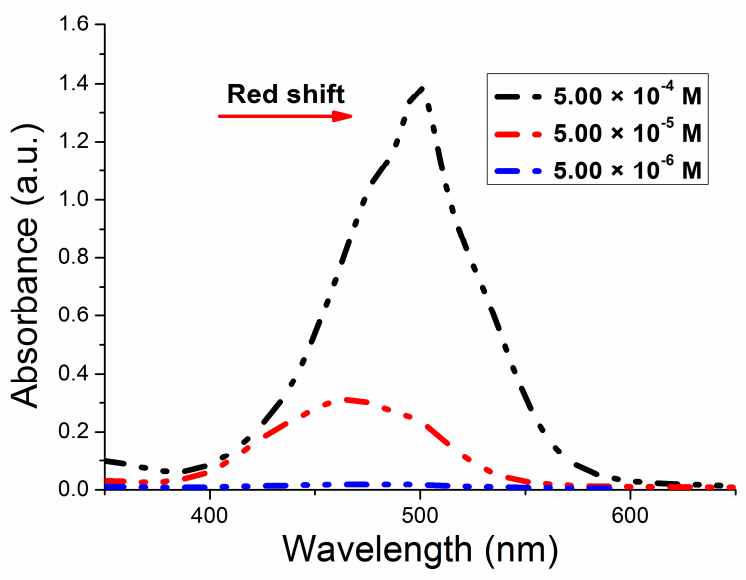

Figure S16. Absorbance spectra of 1 at different concentrations in aqueous PBS buffer solution $\left(1.00 \times 10^{-2} \mathrm{M}\right.$ PBS, $\mathrm{pH}=7.4$ ) at room temperature.

UV/Vis absorption spectra are characteristic of fluorescent chromophore interactions. ${ }^{\text {S3 }}$ Upon addition of WP5 to the solution of $\mathbf{1}$, hypsochromic shifts were seen in the absorption spectrum, indicating the shift to higher energy for WP5 $\supset \mathbf{1}$, which is consistent with H-type aggregation (Figure S15). ${ }^{\mathrm{S} 2}$ On the contrary for $\mathbf{1}$, with the increase of the concentration of $\mathbf{1}$, a shift to lower energy is consistent with J-type aggregation (Figure S16). For the vast majority of fluorophores that show aggregation induced enhanced emission (AIEE) or aggregation-induced emission (AIE), H-aggregates are usually poor emitters, whereas J-aggregates typically show efficient luminescence. ${ }^{\mathrm{S} 4}$ In the case of $\mathbf{1}$ and $\mathbf{W P 5} \supset \mathbf{1}$, previous photophysical studies have established that these rationales are inoperative and that the excited dimer emission is responsible. ${ }^{\mathrm{S} 2}$ 


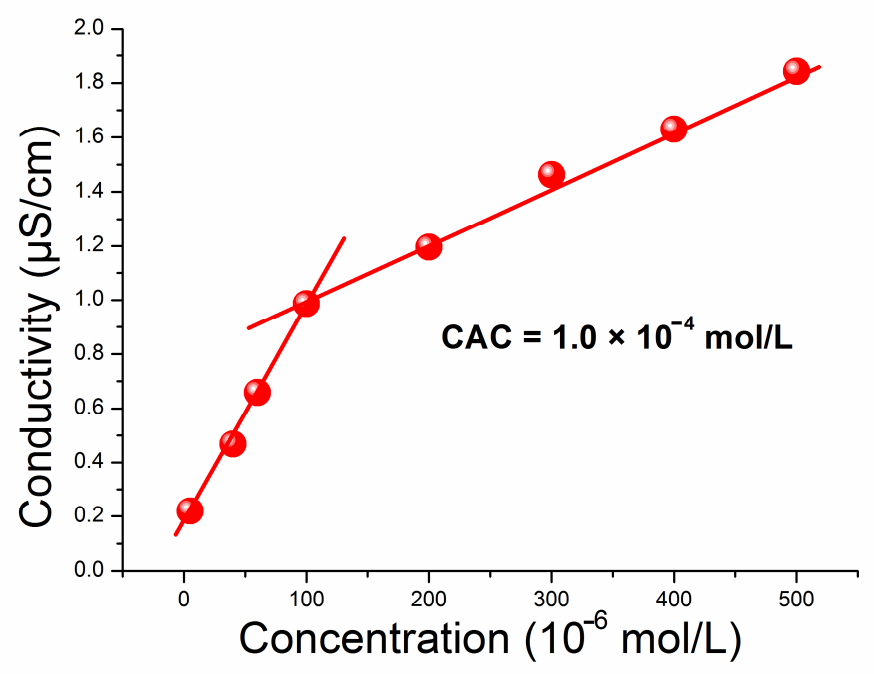

Figure S17. Conductivity as a function of the concentration of $\mathbf{1}$. There are two linear segments in the curve and a sudden reduction of the slope, implying that the critical aggregation concentration (CAC) of $\mathbf{1}$ is approximately $1.00 \times 10^{-4} \mathrm{M}$.

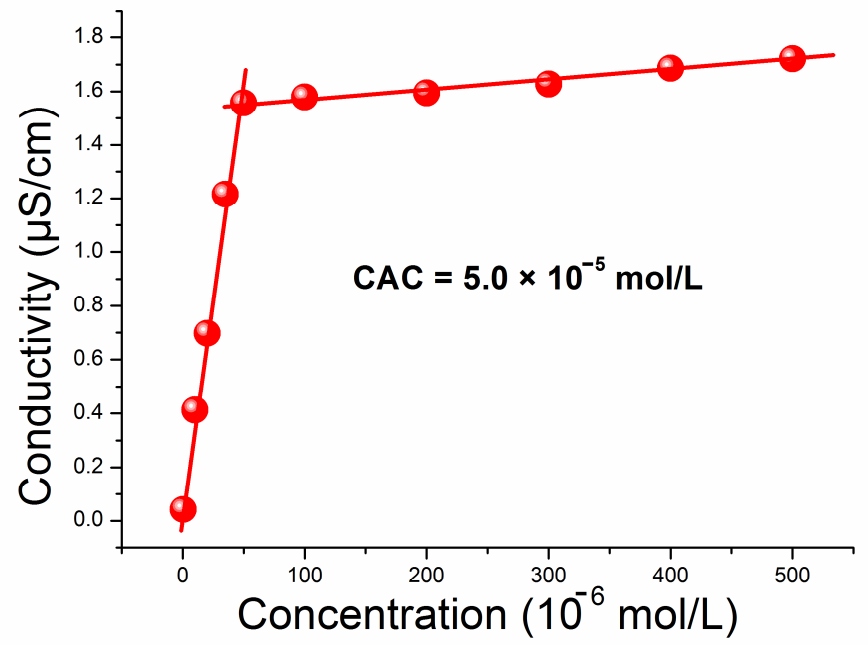

Figure S18. Conductivity as a function of the concentration of WP5 $\supset 1$. There are two linear segments in the curve and a sudden reduction of the slope, implying that the CAC of WP5 $\supset \mathbf{1}$ is approximately $5.00 \times 10^{-5} \mathrm{M}$. 
(a)
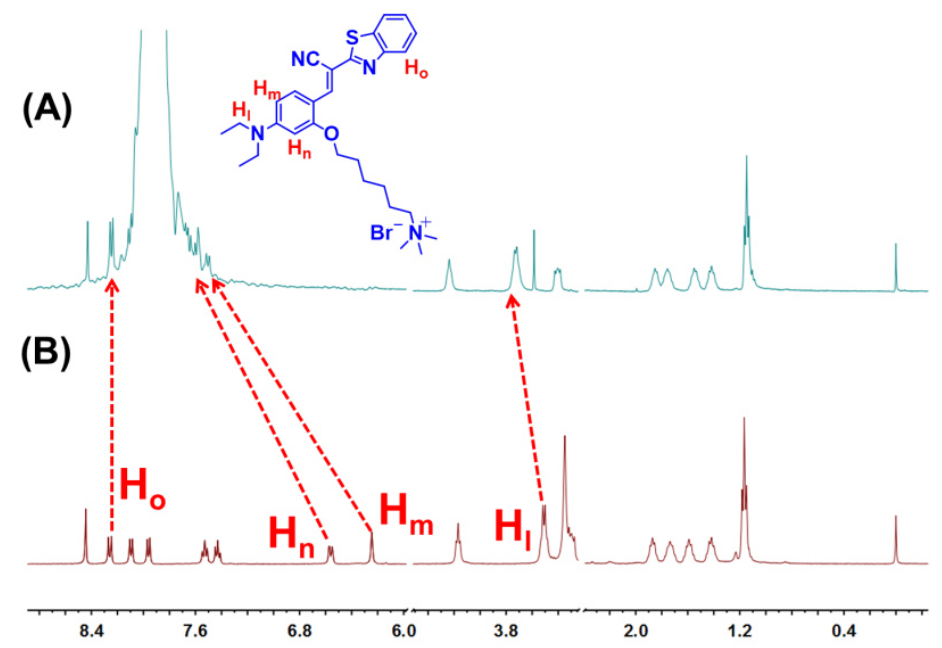

(b)

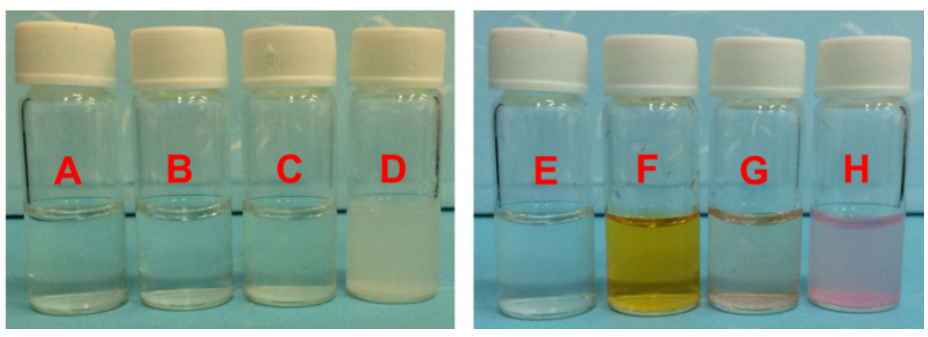

Figure S19. (a) Partial ${ }^{1} \mathrm{H}$ NMR (400 Hz, DMSO- $\left.d_{6}, 293 \mathrm{~K}\right)$ spectra: (A) 1 (10.0 mM); (B) after addition of $\mathrm{HCl}$. (b) Photographs of pure aqueous solutions: (A) WP5; (B) 2; (C) WP5 $\supset$ 2; (D) WP5 $\supset 2+\mathbf{H}^{+}$; (E) WP5; (F) 1; (G) WP5 $\supset \mathbf{1}$; (H) WP5 $\supset \mathbf{1}+\mathbf{H}^{+}$. The concentrations were all $5.00 \times 10^{-5} \mathrm{M}$.

As shown in Figure S19, peaks related to protons $\mathrm{H}_{1}, \mathrm{H}_{\mathrm{m}}$, and $\mathrm{H}_{\mathrm{n}}$ on 1 shifted downfield after the addition of acid. Meanwhile, peaks related to proton $\mathrm{H}_{\mathrm{o}}$ on $\mathbf{1}$ had no chemical shift changes on the proton NMR timescale after the addition of acid. These observations indicated that the nitrogen atom of $\mathbf{1}$ on the diethylamine group was protonated by acid, but the one on the thiazole group was not protonated.

9. DLS studies of the host-guest complex WP5つ1 assemblies
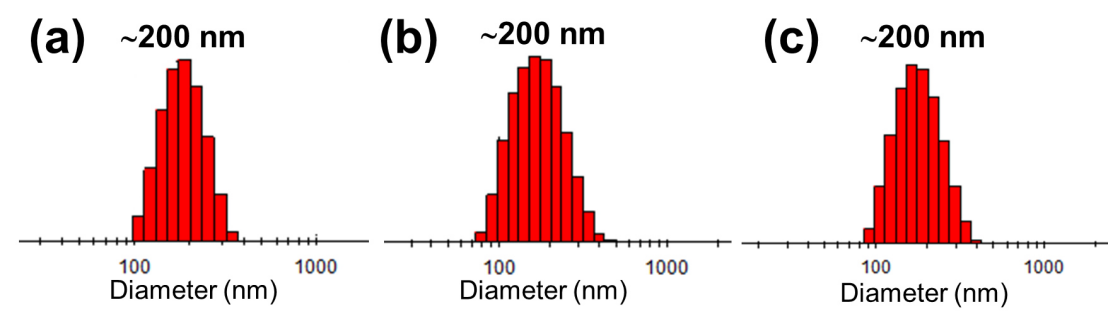

Figure S20. DLS studies of the host-guest complex WP5 $\supset 1$ assemblies at different concentrations: (a) $1.00 \times 10^{-3}$ $\mathrm{M}$; (b) $5.00 \times 10^{-4} \mathrm{M}$; (c) $5.00 \times 10^{-5} \mathrm{M}$. 

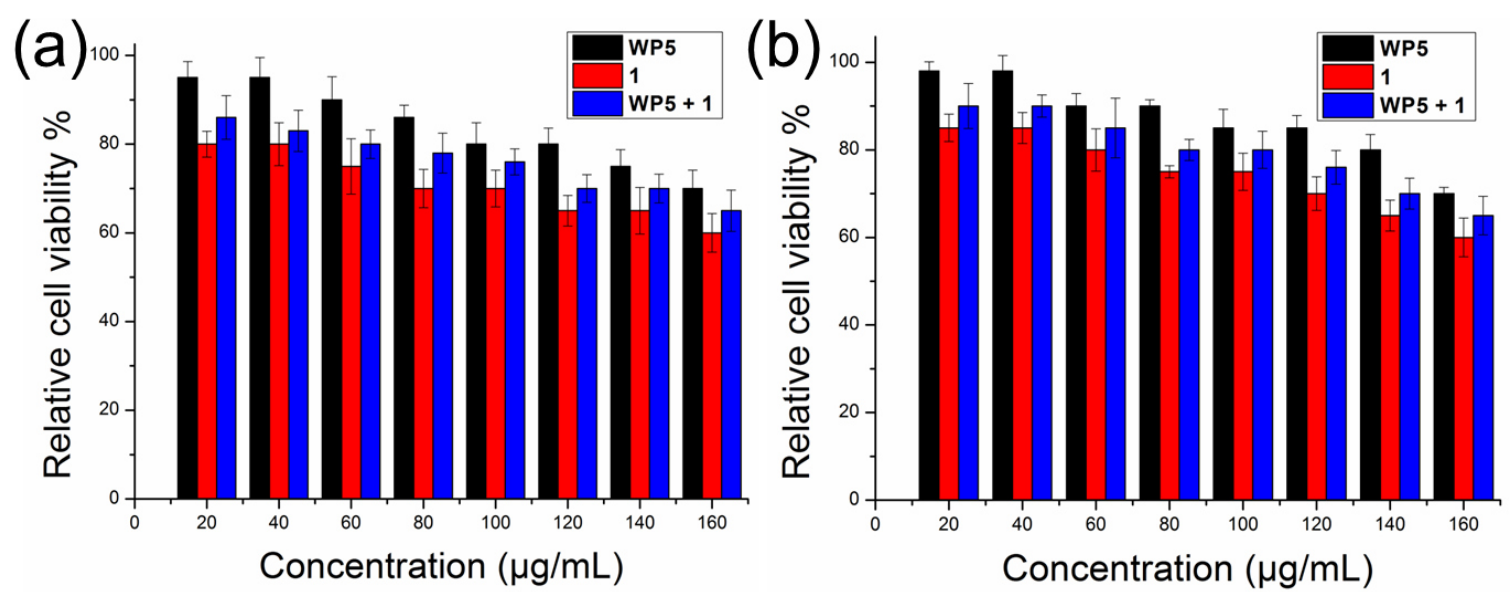

Figure S21. Relative cell viabilities of (a) HeLa cells (4 h) and (b) bEnd.3 cells (4 h) incubated with WP5, 1, and WP5 $\supset 1$, respectively, at different concentrations.

11. Confocal images of live HeLa and bEnd. 3 cells

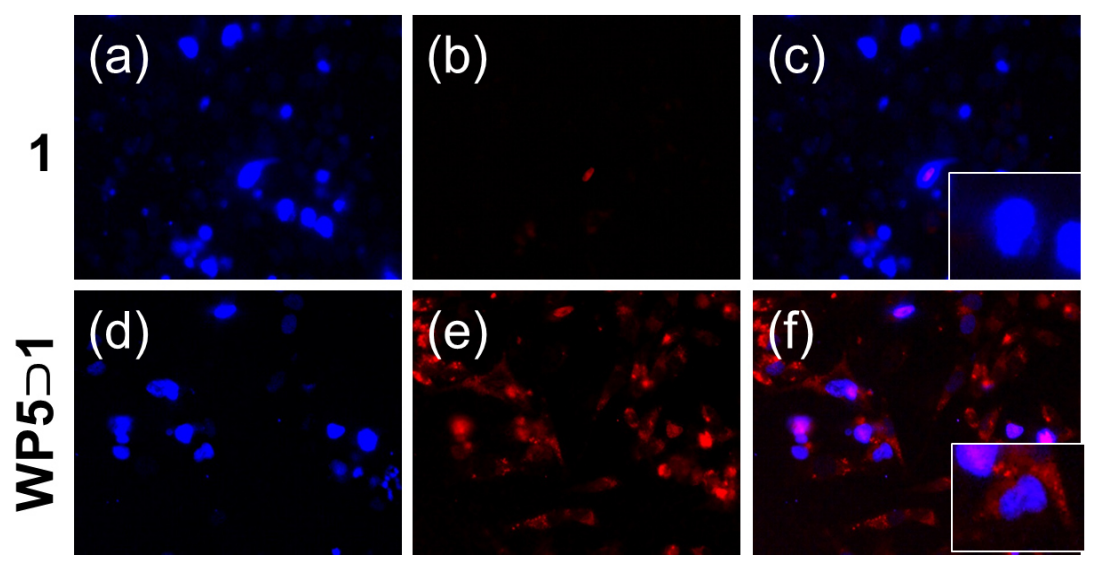

Figure S22. Confocal images of live HeLa cells after incubation with $\mathbf{1}$ and WP5 $\supset \mathbf{1}$ (WP5 $\supset \mathbf{1}$ and $\mathbf{1}$ concentration is $2.00 \times 10^{-4} \mathrm{M}$ ) for $4 \mathrm{~h}$ : (a) and (d) stained with DAPI; (b) and (e) fluorescent image; (c) merged image from (a) and (b); (f) merged image from (d) and (e). Insert showed the single cell. 

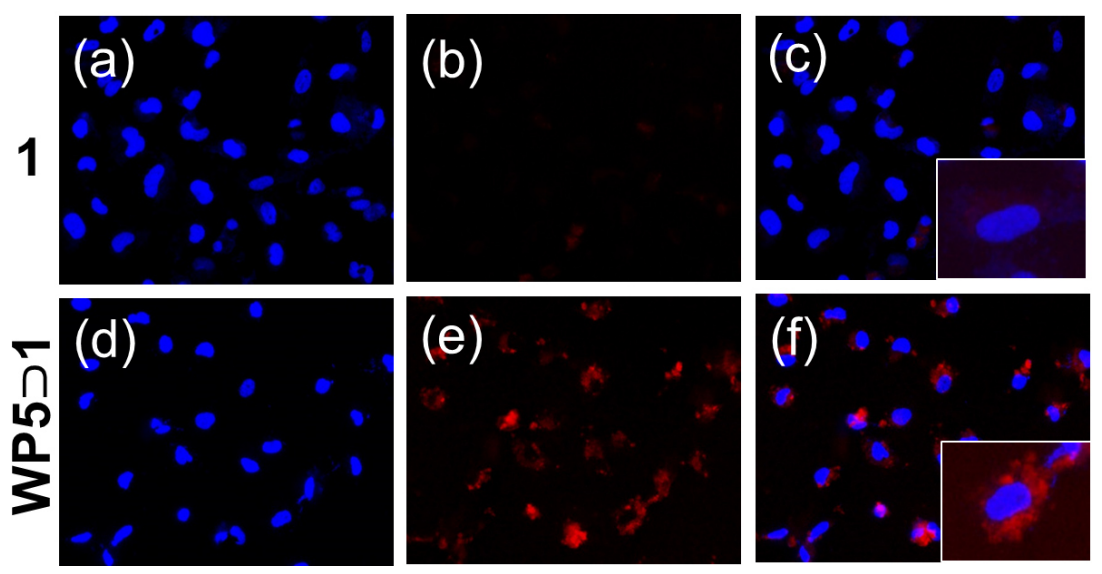

Figure S23. Confocal images of live bEnd.3 cells after incubation with 1 and WP5 $\supset 1$ (WP5 $\supset 1$ and 1 concentration is $2.00 \times 10^{-4} \mathrm{M}$ ) for $4 \mathrm{~h}$ : (a) and (d) stained with DAPI; (b) and (e) fluorescent image; (c) merged image from (a) and (b); (f) merged image from (d) and (e). Insert showed the single cell.

Control experiments were performed by treating HeLa and bEnd.3 cells with 1 for $4 \mathrm{~h}$. As show in Figure S22 and Figure S23, both HeLa and bEnd.3 cells treated with $\mathbf{1}$ had very weak fluorescent emission in the cytoplasm of the cells. However, HeLa and bEnd.3 cells treated with WP5 $\supset \mathbf{1}$ complex at the same concentration exhibited bright red fluorescent emission in the cytoplasm of the cells. These observations indicated that the WP5 $\supset \mathbf{1}$ complex is still intact within the cells.

\section{Cell culture and in vitro cytotoxicity assay}

Cell culture: HeLa and bEnd.3 cells were cultured in Dulbecco's modified Eagle's medium (DMEM) containing $10.0 \%$ fetal bovine serum (FBS) and $1.00 \%$ penicillin/streptomycin. After the cells grew as a monolayer and were detached upon confluence using trypsin $(0.5 \% \mathrm{w} / \mathrm{v}$ in PBS), they were harvested from cell culture medium by incubating in trypsin solution for $5 \mathrm{~min}$. Then, the cells were centrifuged, and the supernatant was discarded. A $3.00 \mathrm{~mL}$ portion of serum-supplemented DMEM was added to neutralize any residual trypsin. Finally, the cells were resuspended in serum-supplemented DMEM at a concentration of $1.00 \times 10^{4}$ cells per mL. Cells were cultured at $37^{\circ} \mathrm{C}$ and $5.00 \% \mathrm{CO}_{2}$.

Evaluation of cytotoxicity: The cytotoxicity of WP5, 1, and WP5 $\supset 1$ against HeLa and bEnd.3 cells was determined by the 3-(4,5-dimethylthiazol-2-yl)-2,5-diphenyl tetrazolium bromide (MTT) assay in a 96-well cell culture plate. All the solutions were sterilized by filtration with a $0.22 \mathrm{~mm}$ filter before tests. Cells were seeded at a density of $1.00 \times 10^{4}$ cells per well in a 96-well plate, and incubated for $24 \mathrm{~h}$ for attachment. Cells were then incubated with WP5, 1, and WP5 $\supset \mathbf{1}$ at various concentrations for $4 \mathrm{~h}$, respectively. Then $20 \mathrm{~mL}$ of MTT solution $(5.00 \mathrm{mg} / \mathrm{mL})$ was added to each well. After $4 \mathrm{~h}$ of incubation 
at $37{ }^{\circ} \mathrm{C}$, the MTT solution was removed, and the insoluble formazan crystals that formed were dissolved in $100 \mathrm{~mL}$ of dimethylsulfoxide (DMSO). The absorbance of the formazan product was measured at 570 nm using a spectrophotometer (Bio-Rad Model 680). Untreated cells in media were used as a control. All experiments were carried out with three replicates.

\section{References:}

S1. (a) Ogoshi, T.; Kanai, S.; Fujinami, S.; Yamagishi, T. A.; Nakamoto, Y. J. Am. Chem. Soc. 2008, 130, 5022-5023. (b) Yu, G.; Xue, M.; Zhang, Z.; Li, J.; Han, C.; Huang, F. J. Am. Chem. Soc. 2012, 134, $13248-13251$.

S2. Han, G.; Kim, D.; Park, Y.; Bouffard, J.; Kim, Y. Angew. Chem. Int. Ed. 2015, 54, 3912-3916.

S3. Kasha, M.; Rawls, H. R.; El-Bayoumi, M. A. Pure Appl. Chem. 1965, 11, 371-392.

S4. Gadde, S.; Batchelor, E. K.; Weiss, J. P.; Ling, Y. H.; Kaifer, A. E. J. Am. Chem. Soc. 2008, 130, 17114-17119. 